\section{Living Wills}

\author{
Max Grinberg and Graziela Zlotnik Chehaibar \\ Instituto do Coração - InCor, São Paulo, SP - Brazil
}

\section{Dear Editor,}

Autonomous decisions should be encouraged and young doctors have been trained to avoid patronizing attitudes toward their patients. The subject of desire together with freedom is an old concept in philosophy; mankind has the sensation of being free during a voluntary act, but one must consider the involvement of conscious and unconscious components $^{1-5}$.

Recently, the Federal Council of Medicine issued Resolution 1995/2012, which provides for advance directives of patients' wills within the concept of orthothanasia, a subject that has assumptions in the Code of Medical Ethics and Resolution 1805/2006. It is understood that aggressive interventions may be not only futile, but also inadequate in the scenario of end-stage illness and inevitable death in the short term.

The manifestation on the types of treatment that patients want from health professionals and caregivers during the end

\section{Keywords}

Living Wills; Right to Die; Bioethics. stage of life, registered while they still have preserved quality of life, is known as the Living Will (LW) and already exists in countries such as Spain, Japan, United States, Portugal and Uruguay. In Brazil, it is being discussed.

End-stage heart failure in the elderly with heart disease brings high relevance to the context of discussions on the use of available methods in cardiology. Therefore, cardiologists should be interested in the context of LWs.

Considering the likelihood that the new generation of doctors will have to deal with patients' Living Wills, we carried out a study with 32 medical residents from the Cardiology Program of Instituto do Coração and obtained the following results: a) $65.3 \%$ have some knowledge on LWs; b) $96.8 \%$ believe that the LW will be useful in decisionmaking, c) $96.8 \%$ believe that patients will make changes in the content of their LWs during the course of the illness d) $84.3 \%$ of doctors would unquestioningly respect their patients' LWs.

The data reflect not only the young doctors' respect for the patients' right to participate actively in decisions concerning their own lives, but also showed good acceptance of the LW as part of the patient's medical record.

Mailing Address: Max Grinberg •

Rua Manoel Antonio Pinto, 04 / 21a, Paraisópolis. Postal Code 05663-020, São Paulo, SP - Brazil

E-mail: max@cardiol.br, grinberg@incor.usp.br

Manuscript received September 04, 2012; revised manuscript September 28, 2012; acepted September 28, 2012.

\title{
References
}

1. Penalva L. Declaração prévia de vontade do paciente terminal. Rev Bioética.2009;17(3):523-43.

2. Costa, RD -Autonomia: viver a própria vida e morrer a própria morte. Cad Saúde Pública. 2006;22(8):1749-54.

3. Van Wijmen MPS, Pasman HRW, Widdershoven GAM, OnwuteakaPhilipsen BD - What do people want at the end of life, with or without an advance directive? BMJ Support Palliat Care.2012;2:195.
4. Silveira MJ, Kim SY, Langa KM -Advance directives and outcomes of surrogate decision making before death. N Engl J Med. 2010;362(13):1211-8.

5. Teno JM, Gruneir A, Schwartz Z, Nanda A, Wetle T. Association between advance directives and quality of end-of-life care: a national study. J Am Geriatr Soc.2007;55(2):189-94. 